Article

\title{
An Unusual Cold February 2019 in Saskatchewan- A Case Study Using NCEP Reanalysis Datasets
}

\author{
Soumik Basu ${ }^{1,2, *}$ and David Sauchyn ${ }^{1,2}$ \\ 1 Prairie Adaptation Research Collaborative, Regina S4S 0A2, Canada \\ 2 Department of Geography and Environmental Studies, University of Regina, Saskatchewan S4S 0A2, Canada \\ * Correspondence: Soumik.Basu@uregina.ca
}

Received: 31 May 2019; Accepted: 1 July 2019; Published: 3 July 2019

\begin{abstract}
In February 2019, central Canada, and especially the province of Saskatchewan, experienced extreme cold weather. It was the coldest February in 82 years and the second coldest in 115 years. In this study, we examine National Centers for Environmental Prediction (NCEP)/National Center for Atmospheric Research (NCAR) Reanalysis 1 data to understand the atmospheric processes leading to this cold snap. A detailed investigation of surface air temperature, sea level pressure, surface fluxes, and winds revealed a linkage between the North Pacific storm track and the February cold snap. A shift in the jet stream pattern triggered by the storm activity over the North Pacific caused a high-pressure blocking pattern, which resulted in unusual cold temperatures in Saskatchewan in February. This study demonstrates the potential for extreme cold in a warming climate; weather records in Saskatchewan show an increase in minimum winter temperature by $4-5{ }^{\circ} \mathrm{C}$.
\end{abstract}

Keywords: extreme cold event; North Pacific storm track; jet stream; high-pressure blocking; Bering Sea ice

\section{Introduction}

The Prairie Provinces of Canada, consisting of Alberta, Saskatchewan, and Manitoba, are well known for their extreme weather [1,2]. In the winter of 2019, Regina, Saskatchewan experienced the coldest February in 82 years and the second coldest in 115 years, with a mean daily minimum temperature of $-28.7^{\circ} \mathrm{C}$, which is $12{ }^{\circ} \mathrm{C}$ colder than the long-term mean February daily minimum temperature of $-16.7^{\circ} \mathrm{C}$ (Figure 1). The winter of 2018-2019 was characterized by a mild December and January followed by an unusually cold February (Figure 2). Although we report daily air temperatures for Regina, a similar extreme cold was seen everywhere in the province of Saskatchewan. Such a prolonged extreme cold event is rare for Saskatchewan with the emergence of a regional signal of anthropogenic climate change over the past 30 years [3]. Such extreme cold temperatures across the region can adversely affect commercial activity, travel, and recreation, and cause property damage from the rupturing of water pipes due to freezing. The objective of this study was to link this rare case of extreme cold in Saskatchewan to large-scale atmospheric patterns and processes during the months of January-February in 2019. 


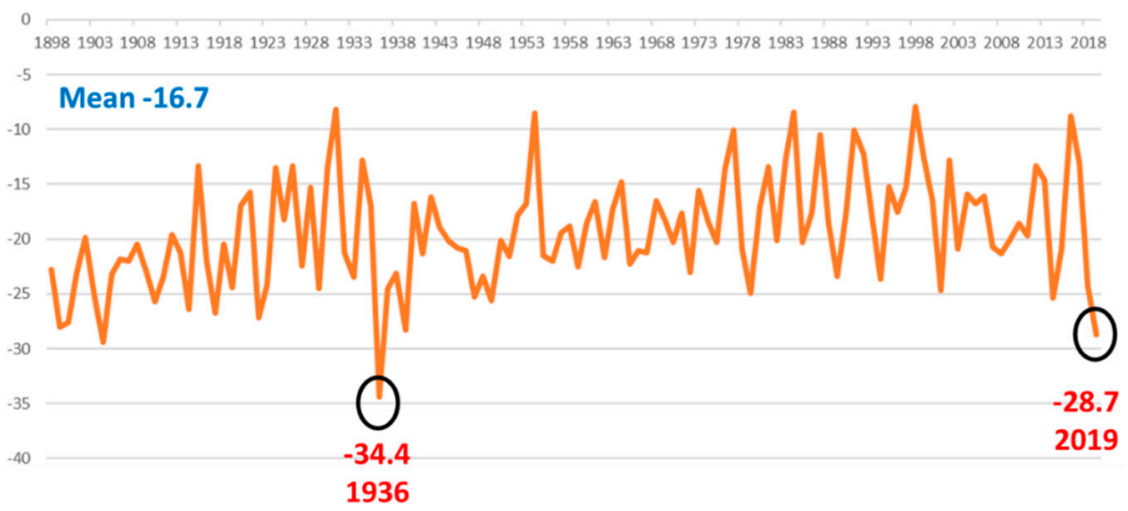

Figure 1. Mean monthly minimum surface air temperature $\left({ }^{\circ} \mathrm{C}\right)$ in Regina, Saskatchewan for February from 1898 to 2019 (Source: Environment and Climate Change Canada).

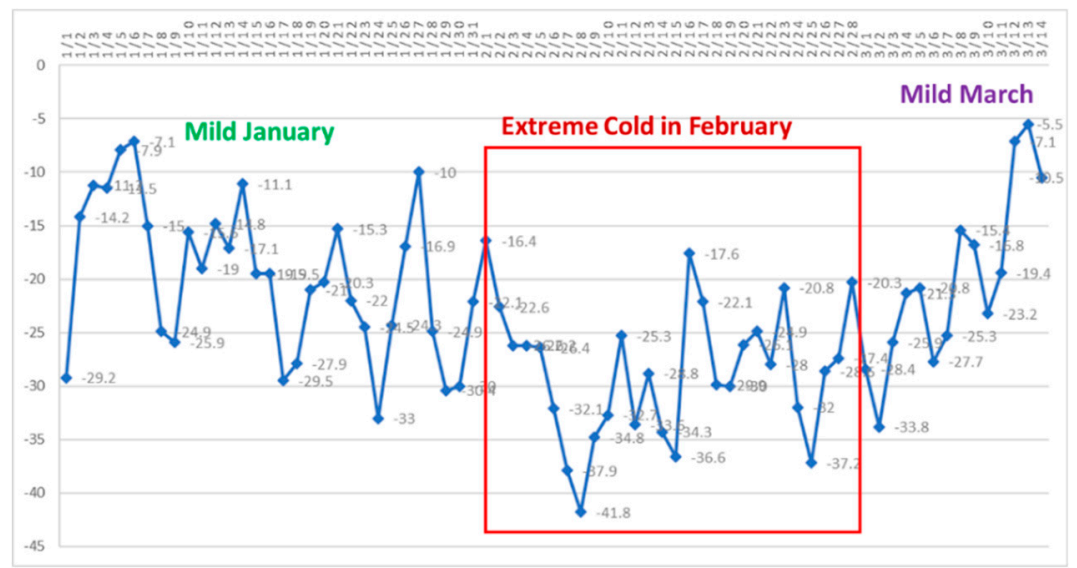

Figure 2. Daily minimum temperature $\left({ }^{\circ} \mathrm{C}\right)$ for 1 January 2019 to 11 March 2019 for Regina, Saskatchewan (Source: Environment and Climate Change Canada).

The weather in Saskatchewan, due to its mid-latitude location, is primarily influenced by the positions of the high and low-pressure systems over the North Pacific, North America and the Arctic. These synoptic weather systems are embedded in the large-scale atmospheric circulation. In winter, high pressure results in a blocking pattern characterized by clear skies with cold dry weather, whereas low pressure is associated with precipitation, wind and cloudy skies with warmer temperatures in winter. The low-pressure systems are extratropical cyclones or frontal cyclones, which develop in the mid-latitudes, i.e., between $40^{\circ} \mathrm{N}$ and $60^{\circ} \mathrm{N}$ latitude due to the convergence of two air masses of contrasting characteristics. The formation and propagation of extratropical cyclones depend on the position and intensity of the jet stream in the upper atmosphere as it provides the required upper level convergence for the development of the storms. Due to their propagation along the jet stream, the storms are the primary contributors of meridional heat and moisture transport in winter [4]. Under the influence of climate change, the northern hemisphere storm tracks have undergone a prominent shift in recent decades $[5,6]$. Future climate scenarios include a poleward shift of the Northern Hemisphere storm tracks [7,8]. Also, interannual variability, associated with El Niño Southern Oscillation (ENSO), causes the jet stream and the North American storm track to shift southward, whereas reduced Arctic sea ice causes increased storm activity over the Arctic $[9,10]$. The synoptic scale extreme weather events are the manifestation of changes in larger-scale circulations related to natural and anthropogenic forcings.

This study investigates the linkage between changes in atmospheric circulation processes and the February 2019 cold snap over Saskatchewan. Our analysis of this unusually cold weather contributes 
to an understanding and explanation of the occurrence of extreme cold weather, in this case diverging from a strong trend of rising winter temperatures.

\section{Datasets and Methodology}

We examined the surface and upper layer atmospheric data from the NCEP/NCAR Reanalysis 1 dataset [11] to understand the atmospheric processes leading to the February 2019 cold snap. The NCEP/NCAR Reanalysis 1 project used the latest analysis methods to generate a global dataset of various atmospheric parameters using data from 1948 to the present. This long time series has been widely used in numerous studies [12]. A few of the non-concerning limitations of this dataset are the low spatial and temporal moisture variability over oceans and its poor performance over the Southern Hemisphere. Historical adjusted and homogenized climate data from Environment and Climate Change Canada [13] were the source of meteorological data for Regina, Saskatchewan.

The domain of our study is centered on the mid- to high-latitude region of western North America, extending from $45^{\circ}$ to $80^{\circ} \mathrm{N}$ and from $170^{\circ} \mathrm{E}$ to $50^{\circ} \mathrm{W}$, and covering most of Canada, the entire state of Alaska, the Bering Sea and the Gulf of Alaska, and the northern continental U.S. Since this study links the changes in local weather to the larger-scale circulation changes, a large domain was selected. A spatial analysis of this domain for five different bi-weekly time segments of 2019-1-15 January; 16-31 January; 1-14 February; 15-28 February; and 1-11 March-revealed the evolution of this extreme cold weather pattern over Saskatchewan. For each time period, we analyzed surface air temperature (SAT), sea level pressure, surface sensible and latent heat fluxes, $250 \mathrm{hPa} u$ and $\mathrm{v}$ components of wind using monthly datasets for the period of January 1981 to December 2010 from the NCEP/NCAR Reanalysis data.

\section{Results}

Figure 3 shows the spatial pattern of surface air temperature (SAT) anomaly $\left({ }^{\circ} \mathrm{C}\right.$ ) over Canada in the months of January, February and March 2019. The strongest positive SAT anomalies are located over Alaska and the Bering and Beaufort Sea regions in all months, with February and March warmer by more than $10^{\circ} \mathrm{C}$. The strongest negative SAT anomalies are located over western Canada in February. The provinces of Saskatchewan, Alberta, and Manitoba exhibit unusually low monthly air temperatures, which are colder than its climatology by more than $10^{\circ} \mathrm{C}$ (1981-2010).

Figure 4 exhibits the bi-weekly patterns of SAT before, during and after the cold snap of February 2019 in Saskatchewan. The coldest temperatures are located over the northeast or the Canadian Archipelago in early January. Then, the cold temperatures over this region extended southwards along the east coast in the second half of January and then shifted westward to Saskatchewan in the first half of February (Figure 4). The extreme cold remained over Saskatchewan for the entire month of February before the pattern weakened in March.

Cold temperatures are often associated with blocking high-pressure systems, so we examined sea level pressure (SLP) (Figure 5). The spatial patterns of SLP in January were characterized by an intense Aleutian Low and North Pacific storm track. In February, however, the Aleutian Low was unusually oriented in a south-north direction over the Bering Strait. The meridionally extended low-pressure pattern was associated with an increased frequency of intense storms over the Bering Sea (Figure 6). Intense high pressure remained stagnant over Saskatchewan as a blocking system for the entire month of February.

The low pressures associated with the synoptic scale surface storms or extratropical cyclones can be spatially represented by high values in transient eddy kinetic energy. Figure 6 shows the transient eddy kinetic energy (EKE) in $\mathrm{KJ} / \mathrm{m}^{2}$ at $1000 \mathrm{hPa}$ which is represented by the following equation, where $u^{\prime}$ and $v^{\prime}$ are deviations of $u$ and $v$ components of wind at each grid point from its long-term monthly mean value at that grid point:

$$
E K E=\frac{1}{2}\left[\left(u-u^{\prime}\right)^{2}+\left(v-v^{\prime}\right)^{2}\right]=\frac{1}{2}\left(u^{\prime 2}+v^{\prime 2}\right)
$$




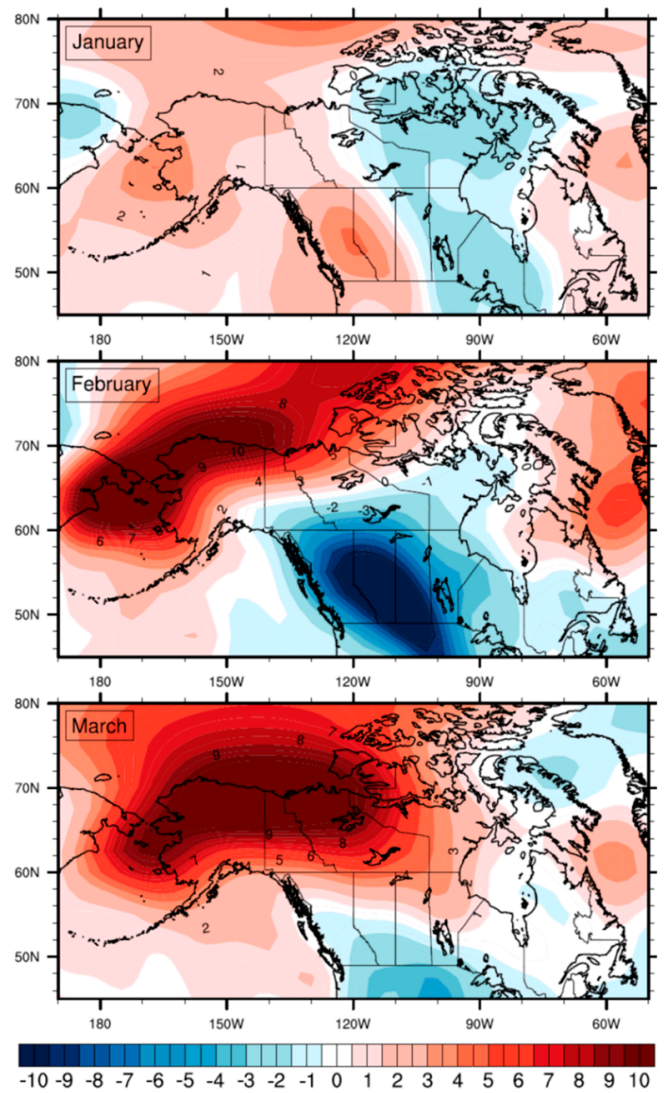

Figure 3. Monthly surface air temperature anomalies $\left({ }^{\circ} \mathrm{C}\right)$ for January-March 2019.

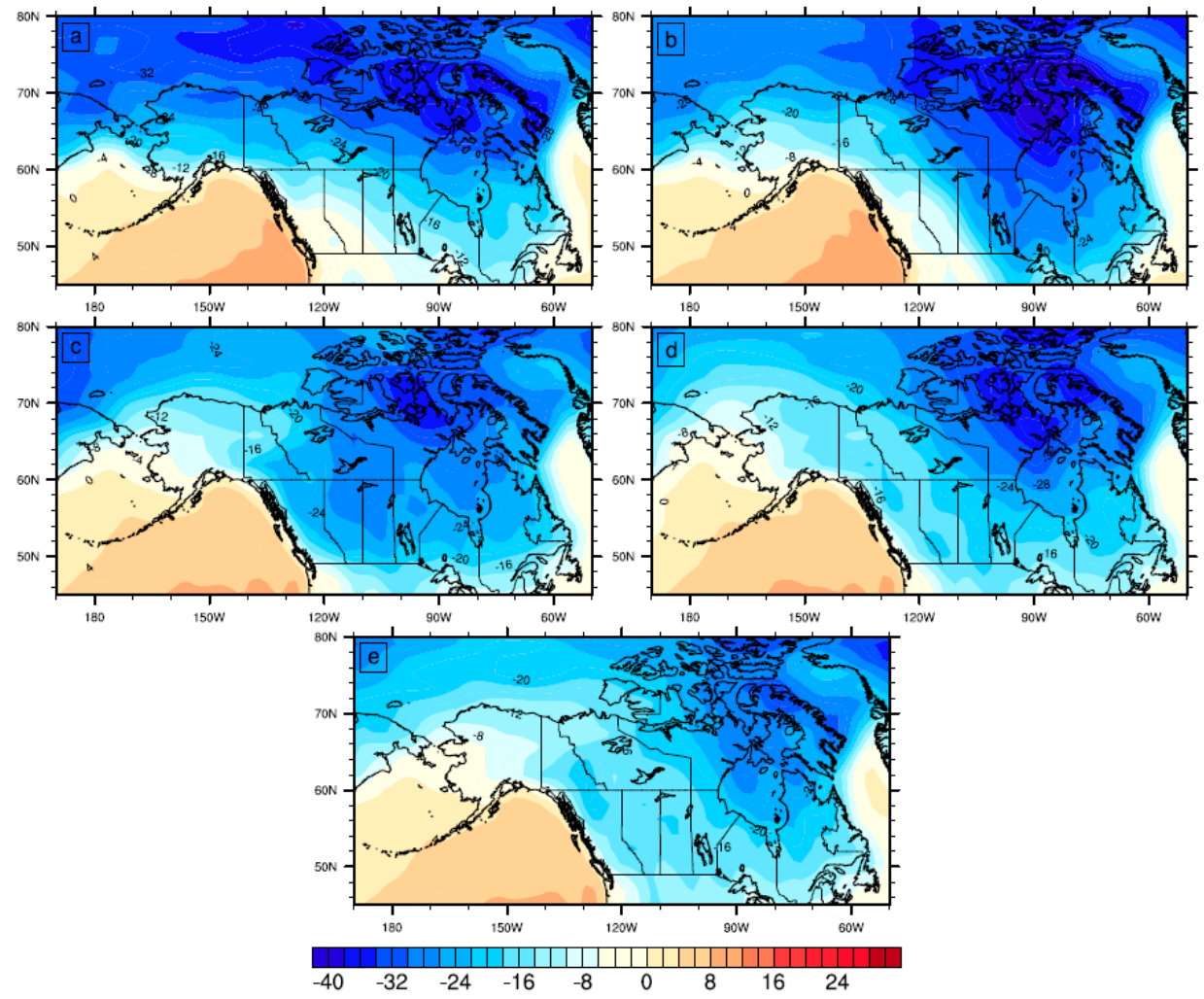

Figure 4. Surface air temperature $\left({ }^{\circ} \mathrm{C}\right.$ ) in (a) 1-15 January; (b) 16-31 January; (c) 1-14 February; (d) 15-28 February; (e) 1-11 March, 2019. 

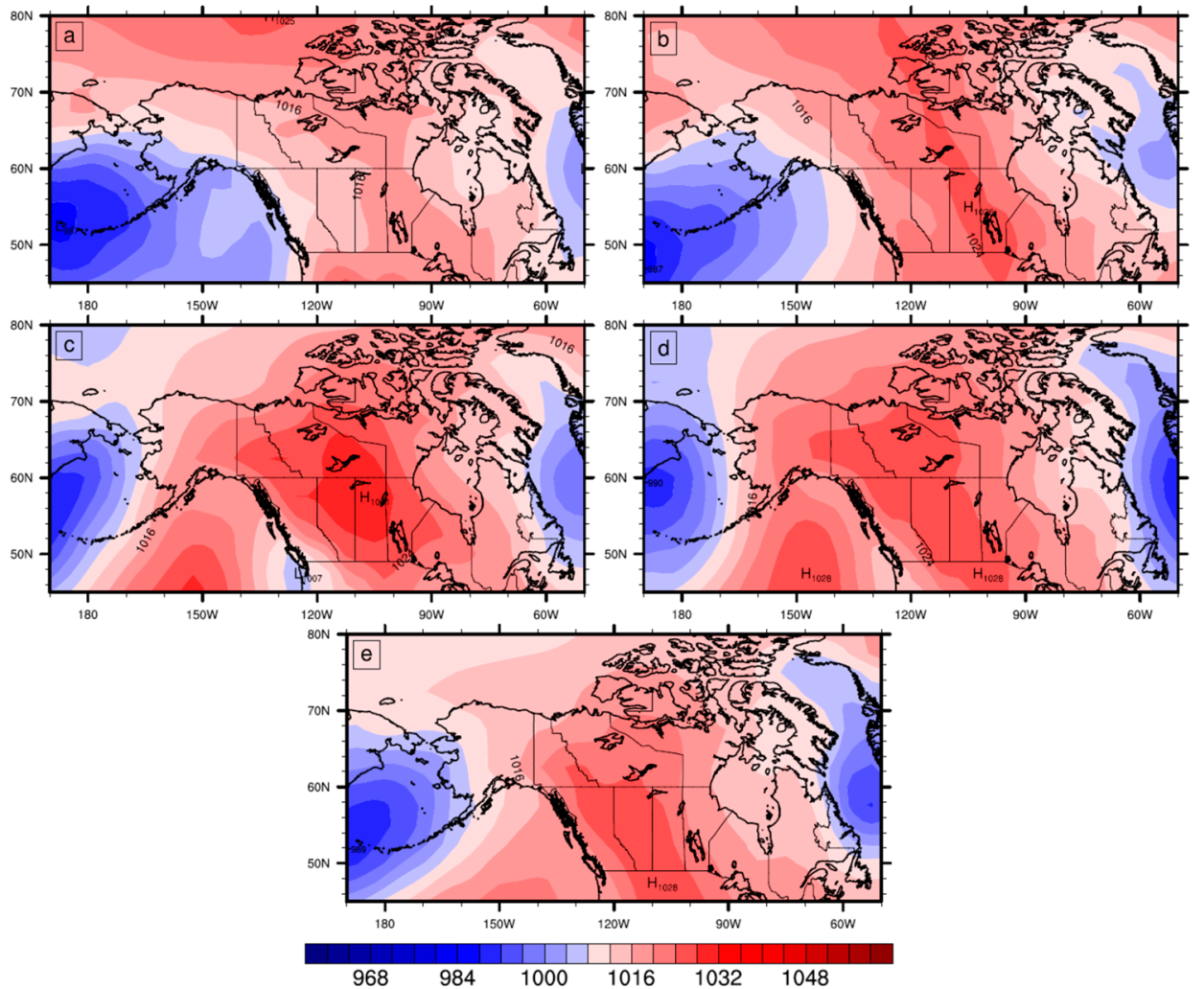

Figure 5. Sea level pressure (hPa) in (a) 1-15 January; (b) 16-31 January; (c) 1-14 February; (d) 15-28 February; (e) 1-11 March 2019.

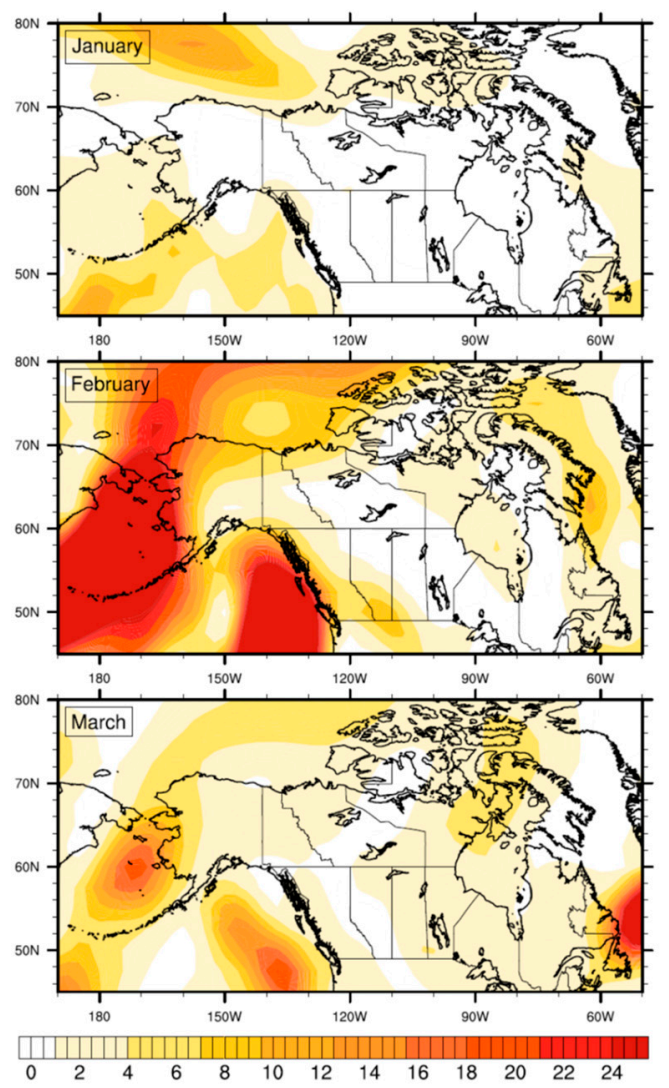

Figure 6. Transient Eddy Kinetic Energy $\left(\mathrm{KJ} / \mathrm{m}^{2}\right)$ in January, February and March 2019. 
Figure 6 shows higher EKE values, representing greater storm activity, in the region of the North Pacific storm track. The strongest storm activity was in February with the North Pacific storm track oriented in a south-north direction along the Bering Strait. The high EKE values in the Beaufort and Chukchi Sea regions indicate the storms propagating deeper into the Arctic in February. The second region of high EKE values corresponds to higher storm activity over the Gulf of Alaska.

The position and propagation of the high-(low-) pressure systems depended on the upper level convergence (divergence) in conjunction with the jet stream. Hence, we then examined $u$ and $v$ components of the wind at $250 \mathrm{hPa}$ (Figure 7). In the first half of January, the upper level wind was oriented from west to east over the mid-latitudes but in the second half of January, it began to curve northwards over the North Pacific region. In February, it meandered further northward with the southerly flow over the Bering Strait and northerly flow over Central Canada. The meridional flow at $250 \mathrm{hPa}$ over the Bering Strait corresponds well with the high storm activities represented by the EKE analysis and the northward extension of the Aleutian Low. This southerly flow of the jet stream steered the storms deeper into the Arctic along the Bering Strait. On the other hand, the strong northerly upper-level flow might have provided favorable atmospheric conditions for sustaining high pressure over south-central Canada in the form of a high-pressure blocking pattern.
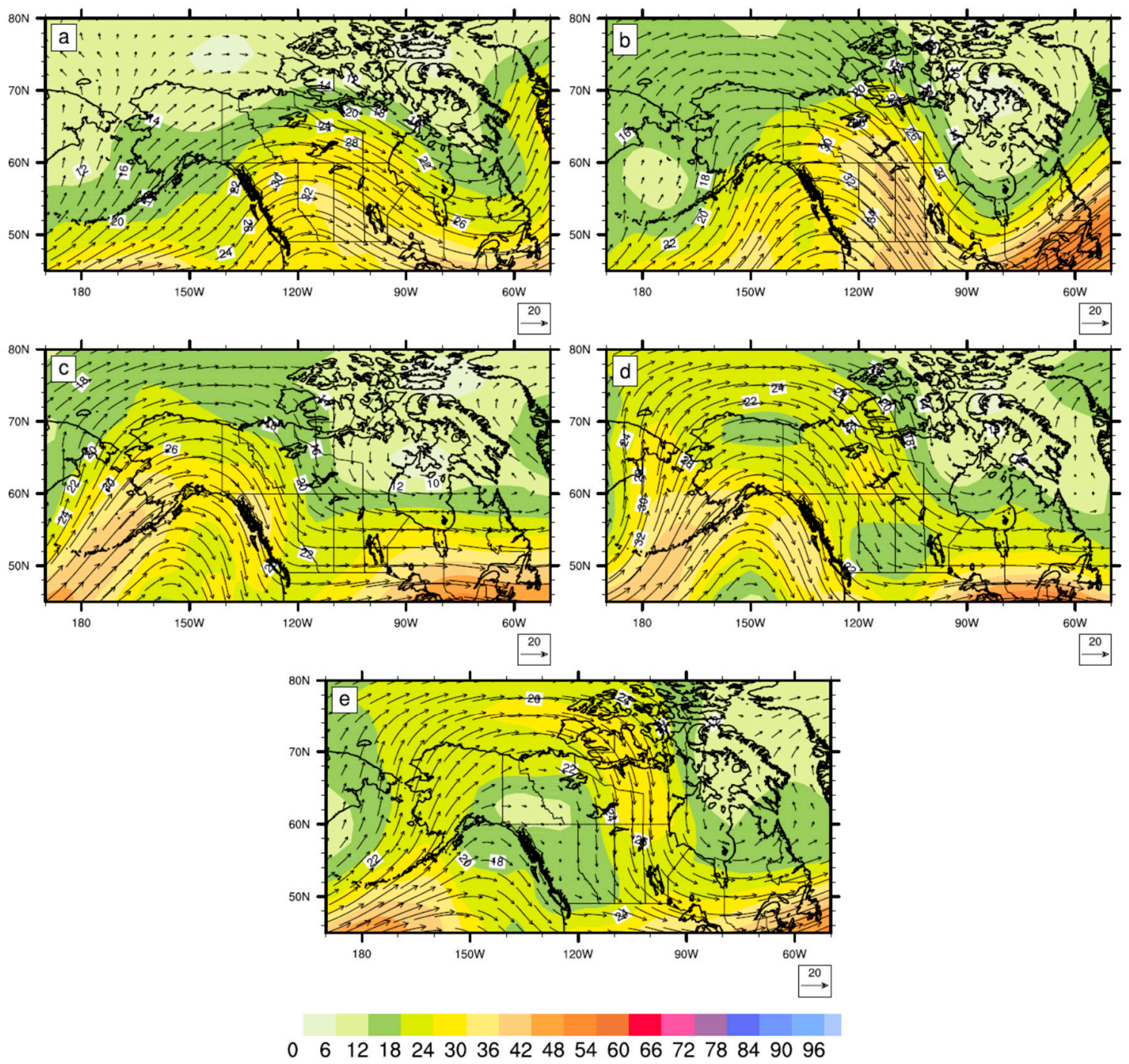

Figure 7. Wind at 250 hPa in (a) 1-15 January; (b) 16-31 January; (c) 1-14 February; (d) 15-28 February; (e) 1-11 March, 2019. 
The jet stream primarily depends on the tropospheric thermal gradient or meridional temperature gradient (MTG). Figure 8 illustrates the spatial distribution of the surface MTG. There are two regions with prominent positive MTG-one over the Chukchi and Beaufort Sea region of the Arctic and another one over the North Pacific. The positive MTG over the North Pacific caused the jet stream to curve northward in the first part of February and the strong MTG over the Arctic Ocean further intensified in the second half of February, causing a further shift in the jet stream and steering the storms deeper into the Arctic.
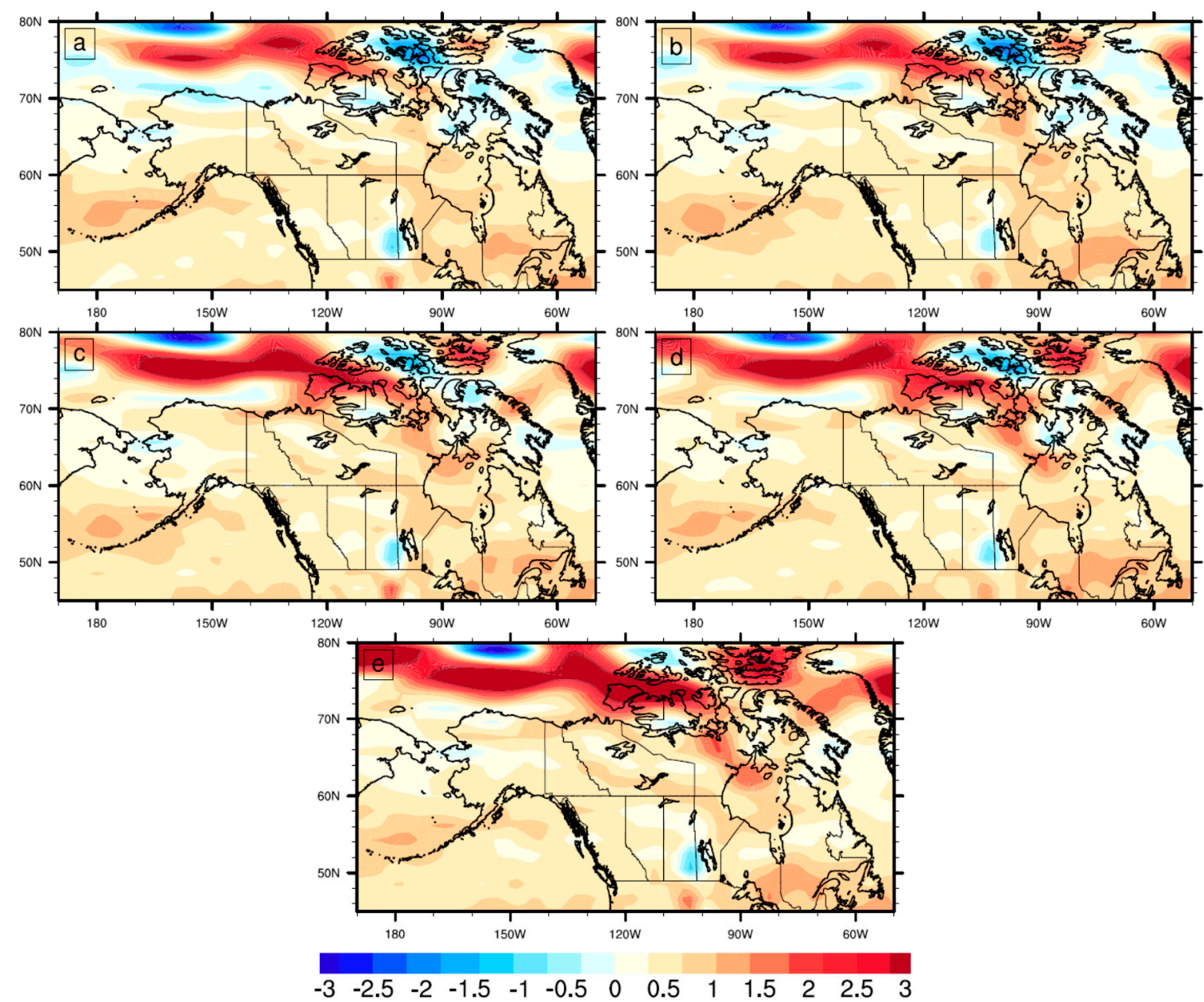

Figure 8. Meridional temperature gradient $\left({ }^{\circ} \mathrm{C} \mathrm{Km}^{-1}\right)$ in (a) 1-15 January; (b) 16-31 January; (c) 1-14 February; (d) 15-28 February; (e) 1-11 March, 2019.

A strong surface flux of sensible and latent heat can cause a redistributed MTG over the North Pacific region. Figures 9 and 10 show the distribution of the sensible and latent heat flux, respectively. The most prominent heat fluxes were over the North Pacific region, especially over the Bering Sea and the Gulf of Alaska in January and February. The region with strong heat fluxes is consistent with the high MTG and high EKE regions. The series of intense storms during the months of January-February might have brought heat from the lower latitudes, resulting in a strong positive MTG over the North Pacific and hence causing the jet stream to shift northward. 

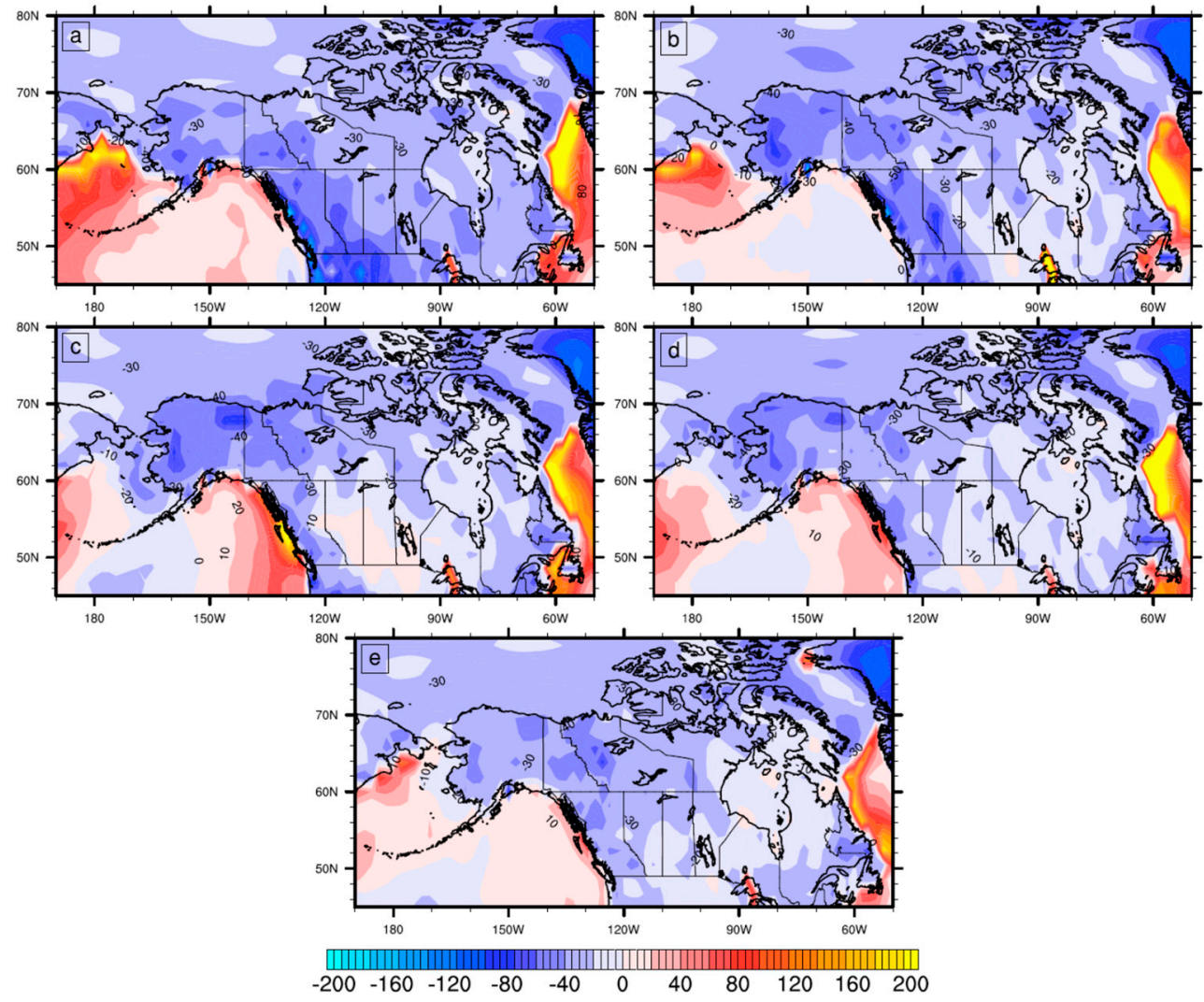

Figure 9. Sensible heat flux $\left(\mathrm{W} \mathrm{m}^{-2}\right)$ in (a) 1-15 January; (b) 16-31 January; (c) 1-14 February; (d) 15-28 February; (e) 1-11 March, 2019.

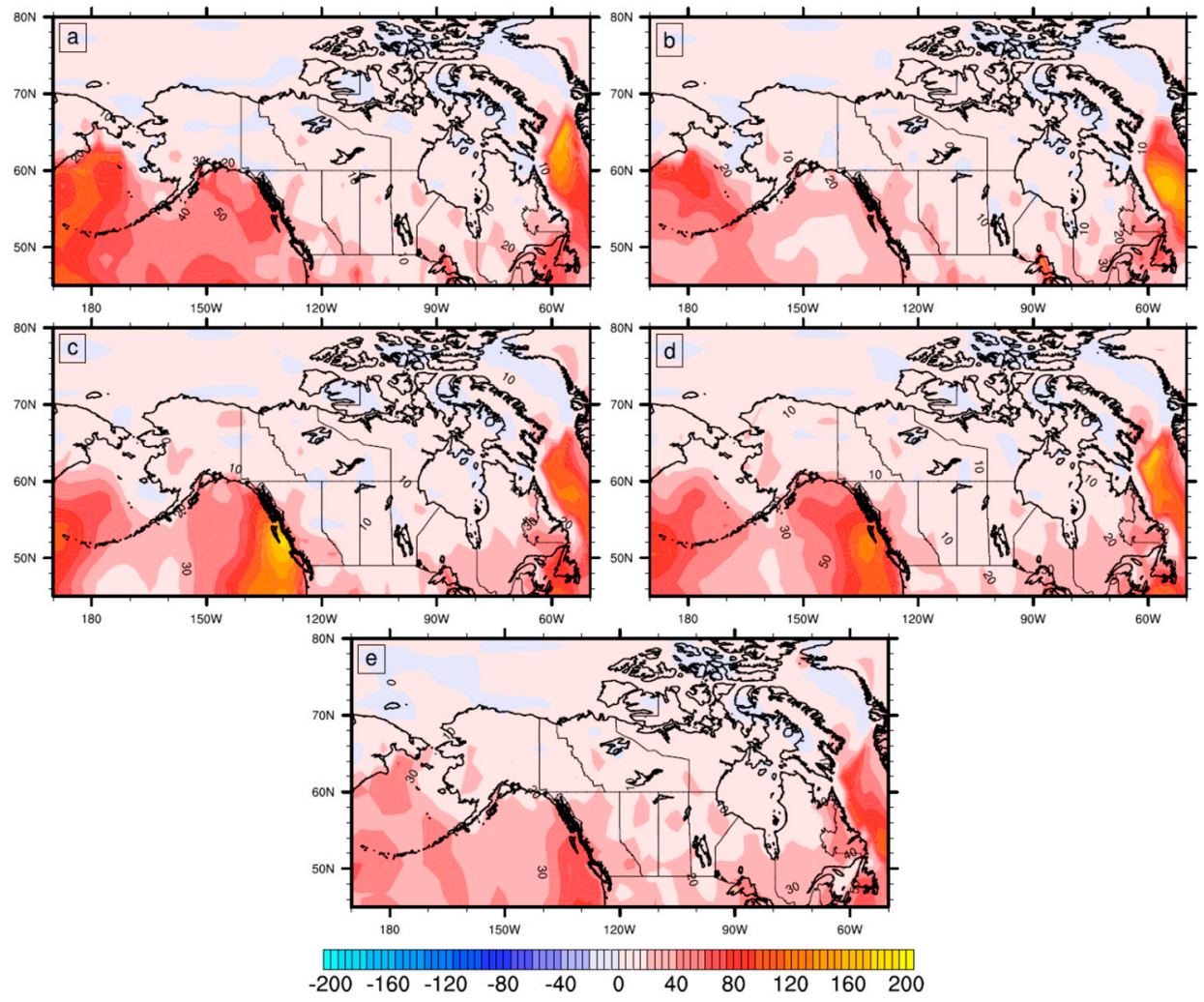

Figure 10. Latent Heat Flux $\left(\mathrm{W} \mathrm{m}^{-2}\right)$ in (a) 1-15 January; (b) 16-31 January; (c) 1-14 February; (d) 15-28 February; (e) 1-11 March, 2019. 
The increased storm activity over the Bering Strait in February, due to the shift in the jet stream, forced the storms and transport of heat deeper into the Arctic. In the process of increased storm activity (15 storms between 27 January and 3 March) and enhanced heat flux and gusty winds, the Bering sea lost 373,000 sq. km of sea ice between 27 January and 3 March and had the lowest recorded sea ice in March (Figure 11). The extended open water further contributed to the heat fluxes into the lower troposphere. Thus, the storm activity over the North Pacific triggered a series of changes in atmospheric circulation indirectly linked to the extreme cold event over the Prairie region of Canada.

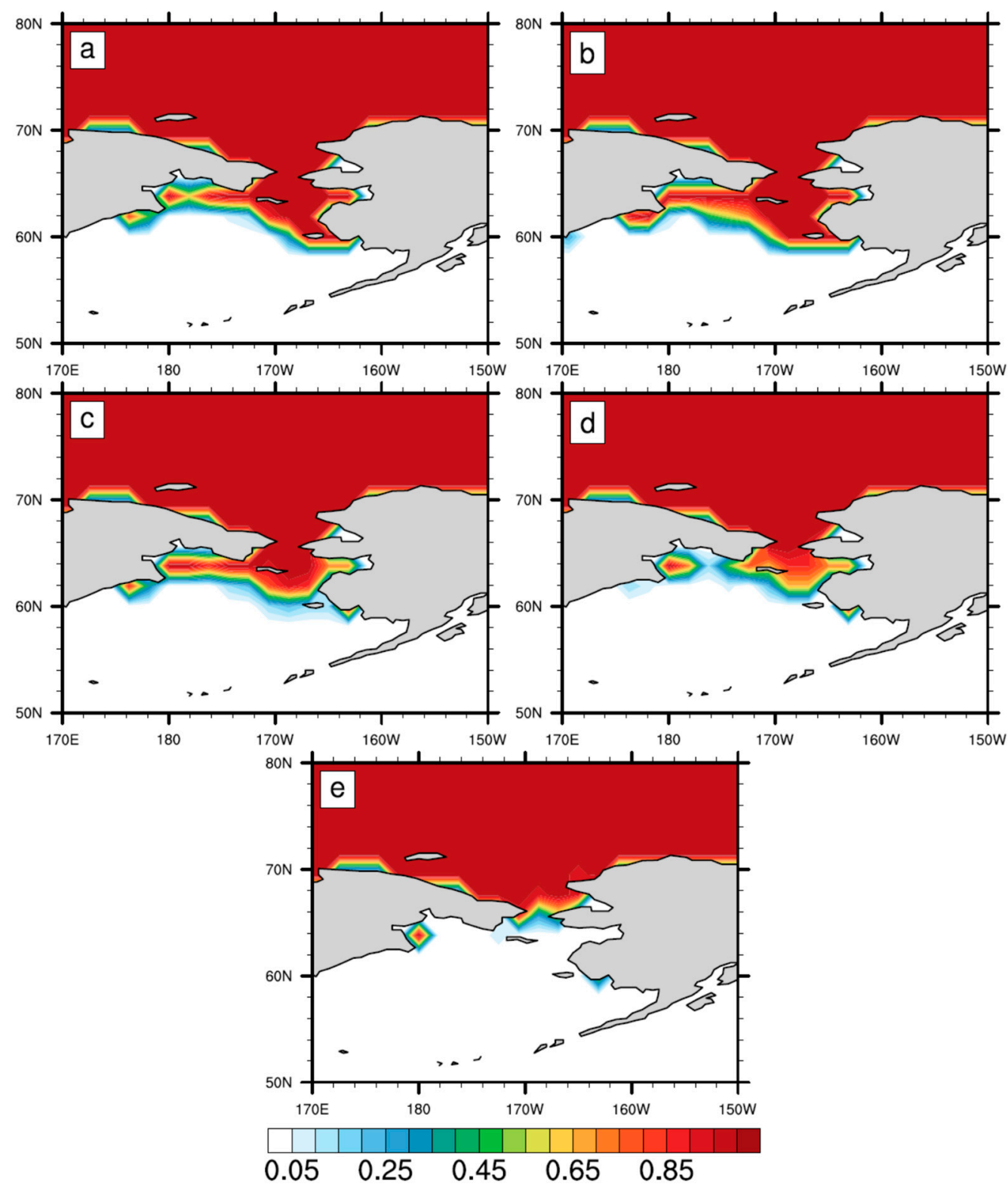

Figure 11. Sea ice concentration in the Bering Sea in (a) 1-15 January; (b) 16-31 January; (c) 1-14 February; (d) 15-28 February; (e) 1-11 March, 2019.

A further investigation of the time series of the changes in the atmospheric parameters at two arbitrarily selected points over the Bering Sea $\left(60^{\circ} \mathrm{N}, 175^{\circ} \mathrm{W}\right)$ and Saskatchewan $\left(50.4^{\circ} \mathrm{N}, 104.5^{\circ} \mathrm{W}\right)$ revealed the indirect linkage between North Pacific and Prairie region weather systems. A higher storm activity, i.e., a high EKE over the Bering Sea region, is consistent with a stronger MTG, accompanied by a phase shift of the jet stream to dominant southerly flow over the region (Figure 12). At the same time, 
Saskatchewan is dominated by colder daily mean temperatures, which correspond well with the high pressure (Figure 13).

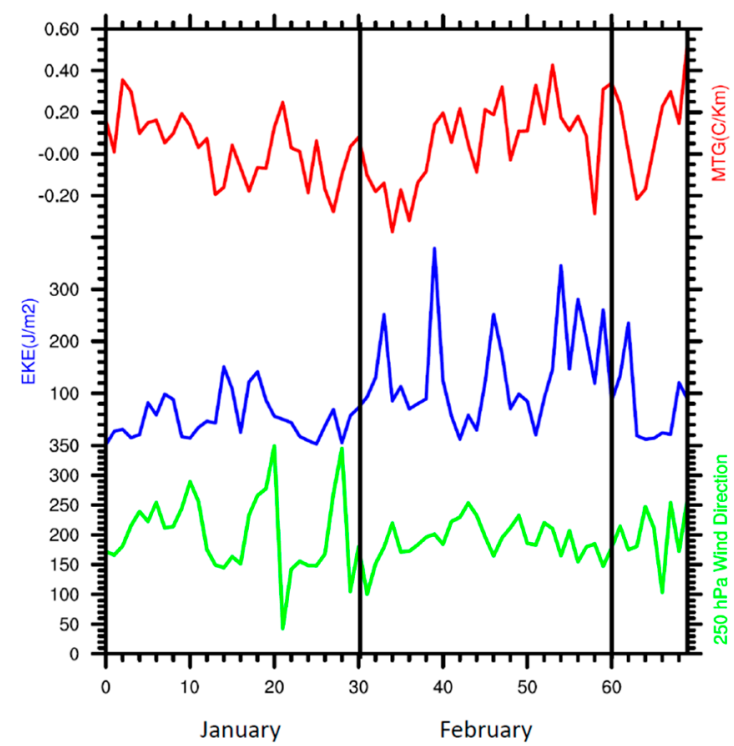

Figure 12. Time series of daily meridional temperature gradient $\left({ }^{\circ} \mathrm{C} \mathrm{Km}^{-1}\right)$, Eddy Kinetic Energy $\left(\mathrm{J} / \mathrm{m}^{2}\right)$ and $250 \mathrm{hPa}$ wind direction (in degrees) over the Bering Sea region.

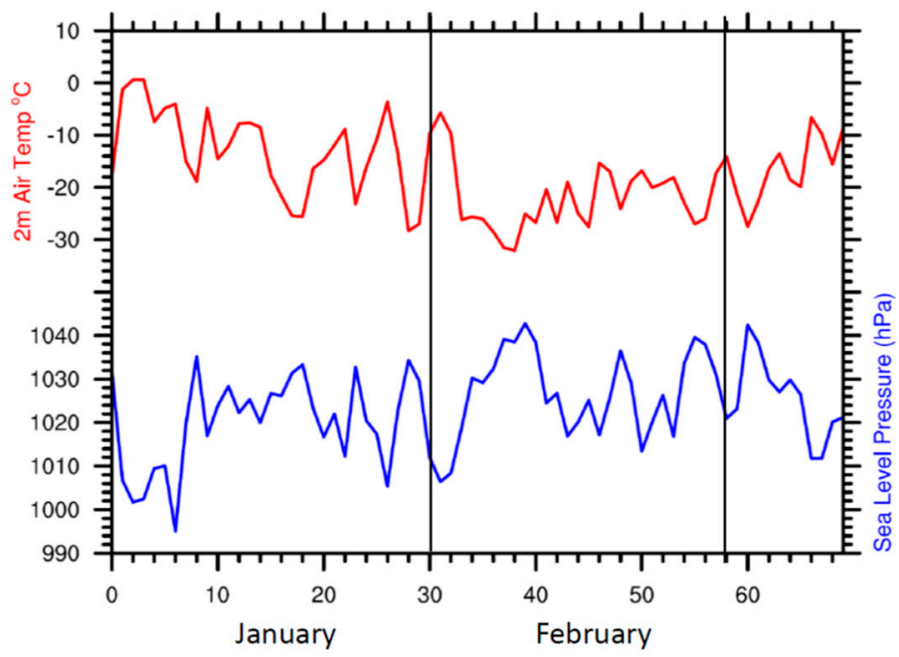

Figure 13. Time series of daily mean temperature $\left({ }^{\circ} \mathrm{C}\right)$ and sea level pressure $(\mathrm{hPa})$ over the Prairie region.

\section{Discussion and Summary}

In February 2019, the province of Saskatchewan experienced extreme cold temperatures after a relatively mild December and January. We investigated the atmospheric circulation processes associated with this extreme cold event by examining surface air temperature, sea level pressure, surface heat fluxes, and upper level wind using the NCEP/NCAR Reanalysis dataset. We found:

(1) Increased storm activity over the Bering Sea region, causing enhanced sensible and latent heat fluxes over the North Pacific in January-February.

(2) A strong meridional temperature gradient over the North Pacific and the Arctic, causing a shift in the jet stream.

(3) An unusual upper-level wind pattern favored by high-pressure blocking over southwestern Canada, especially in the Prairie Provinces of Saskatchewan, Alberta, and Manitoba, which brought the extreme cold temperatures in February. 
In the field of climate science, no phenomena are local. Interannual variability like El Niño and the natural variability of Arctic sea ice are known to influence the mid-latitude climate through alteration of atmospheric circulations [14-24], but 2018-2019 was neither an El Niño year nor a record low Arctic sea ice. In February 2019, the shifts in atmospheric circulation, which indirectly resulted in the extreme cold weather over Saskatchewan, started, and can be attributed to the strong heat fluxes over the North Pacific caused by the intense storms over the region. The extratropical cyclones transported heat from the lower latitudes to the North Pacific and the Bering Sea region. The strong, sensible and latent heat flux caused a prominent positive meridional temperature gradient over the North Pacific, along with the presence of a stronger MTG over the Chukchi and Beaufort Sea region. As a result, the jet stream curved further northward and steered the storms through the Bering Strait deeper into the Arctic. For most of February, an unusual jet stream pattern prevailed, with a southerly flow over the Bering Strait and a northerly flow over central Canada. This northerly component of the upper level flow provided the favorable atmospheric condition for the formation of high-pressure blocking over Saskatchewan, Alberta, and Manitoba. The high-pressure blocking pattern produced the lowest February temperatures in 82 years in Saskatchewan, with cold temperature advection from the Arctic and radiational cooling under clear sky conditions.

We conclude that the record cold event in the Prairie region of Canada is indirectly linked to the record low sea ice event in the Bering Sea through the changes in storm activity over the North Pacific and a pattern shift of the jet stream. The changes in jet stream pattern documented in this study correspond well with the previous findings of recent jet stream variability, in conjunction with the warming climate [25,26]. However, this study and the proposed mechanism is limited to the cold event of 2019 only and we are not proposing a generalized mechanism as there was no recorded history of such widespread extreme cold events since 1936.

This study demonstrates that governments and municipalities should be prepared for such cold weather events in the future, despite the strong upward trend in minimum winter temperatures. We documented shifts in atmospheric circulation and processes that can produce weeks of extreme cold weather in the midst of a warming climate. The potential for these events should be considered in extreme weather preparedness and adaption planning.

Author Contributions: S.B. designed the research and conducted the data analysis, figure preparation, and manuscript writing. S.B. and D.S. interpreted the result. D.S. also supervised the research and helped in enhancing the overall quality of the paper.

Funding: This study was funded "Queen Elizabeth Scholarship Program" and Natural Sciences and Engineering Research Council (NSERC).

Acknowledgments: We would like to thank "Queen Elizabeth Scholarship Program" and Natural Sciences and Engineering Research Council (NSERC) for providing funding for this study. We would also like to thank Compute Canada for providing the computational support for this research. We would also like to thank NOAA/OAR/ESRL PSD, Boulder, Colorado, USA, for providing NCEP Reanalysis data from their website at https://www.esrl.noaa.gov/psd/.

Conflicts of Interest: The authors declare no conflict of interest.

\section{References}

1. Wheaton, E. But It's a Dry Cold; Fifth House Publishers: Calgary, AB, Canada, 1998.

2. Sauchyn, D.; Diaz, H.; Kulshrestha, S. The New Normal; Canadian Plain Research Center Press: Regina, SK, Canada, 2010.

3. Barrow, E.B.; Sauchyn, D.J. Uncertainty in climate projections and time of emergence of climate signals in western Canada. Int. J. Clim. 2009. [CrossRef]

4. Wu, Y.; Ting, M.; Seager, R.; Huang, H.-P.; Cane, M.A. Changes in storm tracks and energy transports in a warmer climate simulated by the GFDL CM2.1 model. Clim. Dyn. 2011, 37, 53-72. [CrossRef]

5. Basu, S.; Zhang, X.; Wang, Z. Eurasian Winter Storm Activity at the End of the Century: A CMIP5 Multi-model Ensemble Projection. Earth's Future 2018, 6, 61-70. [CrossRef] 
6. Zhang, X.; Walsh, J.E.; Zhang, J.; Bhatt, U.S.; Ikeda, M. Climatology and interannual variability of Arctic cyclone activity: 1948-2002. J. Clim. 2004, 17, 2300-2317. [CrossRef]

7. McCabe, G.J.; Clark, M.P.; Serreze, M.C. Trends in Northern Hemisphere surface cyclone frequency and intensity. J. Clim. 2001, 14, 2763-2768. [CrossRef]

8. Yin, J.H. A consistent poleward shift of the storm tracks in simulations of 21st century climate. Geophys. Res. Lett. 2005, 32, 1-4. [CrossRef]

9. Basu, S.; Zhang, X.; Polyakov, I.; Bhatt, U.S. North American winter-spring storms: Modeling investigation on tropical Pacific sea surface temperature impacts. Geophys. Res. Lett. 2013, 40, 5228-5233. [CrossRef]

10. Basu, S.; Zhang, X.; Wang, Z. A Modeling Investigation of Northern Hemisphere Extratropical Cyclone Activity in Spring: The Linkage between Extreme Weather and Arctic Sea Ice Forcing. Climate 2019, 7, 25. [CrossRef]

11. Kalnay, E.; Kanamitsu, M.; Kistler, R.; Collins, W.; Deaven, D.; Gandin, L. The NCEP/NCAR 40-Year Reanalysis Project. Bull. Am. Meteorol. Soc. 1996. [CrossRef]

12. Reid, P.A.; Jones, P.D.; Brown, O.; Goodess TDDavies, T.M. Assessments of the reliability of NCEP circulation data and relationships with surface climate by direct comparisons with station based data. Clim. Res. 2001, 17, 247-261. [CrossRef]

13. Vincent, L.A.; Wang, X.L.; Milewska, E.J.; Wan, H.; Yang, F.; Swail, V. A second generation of homogenized Canadian monthly surface air temperature for climate trend analysis. J. Geophys. Res. 2012, 117, 1-13. [CrossRef]

14. Budikova, D. Role of Arctic sea ice in global atmospheric circulation: A review. Glob. Planet. Chang. 2009, 68, 149-163. [CrossRef]

15. Honda, M.; Inoue, J.; Yamane, S. Influence of low Arctic sea ice minima on anomalously cold Eurasian winters. Geophys. Res. Lett. 2009, 36, L08707. [CrossRef]

16. Balmaseda, M.A.; Ferranti, L.; Molteni, F.; Palmer, T.N. Impact of 2007 and 2008 Arctic ice anomalies on the atmospheric circulation: Implications for long-range predictions. Q. J. R. Meteorol. Soc. 2010, 136, 1655-1664. [CrossRef]

17. Overland, J.E.; Wang, M. Large-scale atmospheric circulation changes are associated with the recent loss of Arctic sea ice. Tellus A 2010, 62, 1-9. [CrossRef]

18. Overland, J.E.; Wang, M.; Walsh, J.E.; Stroeve, J.C. Future Arctic climate changes: Adaptation and mitigation time scales. Earth's Future 2014, 2, 68-74. [CrossRef]

19. Overland, J.; Francis, J.A.; Hall, R.; Hanna, E.; Kim, S.J.; Vihma, T. The Melting Arctic and Midlatitude Weather Patterns: Are They Connected? J. Clim. 2015, 28, 7917-7932. [CrossRef]

20. Wu, Q.; Zhang, X. Observed forcing-feedback processes between Northern Hemisphere atmospheric circulation and Arctic sea ice coverage. J. Geophys. Res. 2010, 115, D14119. [CrossRef]

21. Blüthgen, J.; Gerdes, R.; Werner, M. Atmospheric response to the extreme Arctic sea ice conditions in 2007. Geophys. Res. Lett. 2012, 39, L02707. [CrossRef]

22. Francis, J.A.; Vavrus, S.J. Evidence linking Arctic amplification to extreme weather in mid-latitudes. Geophys. Res. Lett. 2012, 39, L06801. [CrossRef]

23. Screen, J.A.; Simmonds, I. Exploring links between Arctic amplification and mid-latitude weather. Geophys. Res. Lett. 2013, 40, 959-964. [CrossRef]

24. Cohen, J.; Screen, J.A.; Furtado, J.C.; Barlow, M.; Whittleston, D.; Coumou, D.; Francis, J.; Dethloff, K.; Entekhabi, D.; Overland, J.; et al. Recent Arctic amplification and extreme mid-latitude weather. Nat. Geosci. 2014, 7, 627-637. [CrossRef]

25. Romanowsky, E.; Handorf, D.; Jaiser, R.; Wohltmann, I.; Dorn, W.; Ukita, J.; Cohen, J.; Dethloff, K.; Rex, M. The role of stratospheric ozone for Arctic-midlatitude linkages. Sci. Rep. 2019, 9, 7962. [CrossRef]

26. Overland, J.E.; Wang, M. Resolving future Arctic/Midlatitude weather connections. Earth's Future 2018, 6, 1146-1152. [CrossRef]

(C) 2019 by the authors. Licensee MDPI, Basel, Switzerland. This article is an open access article distributed under the terms and conditions of the Creative Commons Attribution (CC BY) license (http://creativecommons.org/licenses/by/4.0/). 